\title{
An hypothesis on the aetiology of obesity: dysfunction of the central nervous system as a primary cause
}

\author{
B.Jeanrenaud \\ Laboratoires de Recherches Métaboliques, University of Geneva Medical School, Geneva, Switzerland
}

The topics I was studying when I received the 1970 Minkowski Award were the the regulation of adipose tissue metabolism and the mechanism of insulin secretion. I had shown, as had several others, that adipose tissue was not as inert as it had been claimed to be for years but that it was very active metabolically and under the control of many hormones, insulin in particular. In collaboration with Doctor A. Lambert at the Institut de Biochimie clinique of Professor A. E. Renold we had also demonstrated, albeit indirectly, that insulin secretion was a cyclic AMP-dependent process [1].

In 1971, I started a new research group, the "Laboratoires de Recherches Métaboliques", Faculty and Department of Medicine (Geneva) of which I had been nominated Professor and Head by the State of Geneva. I also moved to a new building, the "Fondation pour Recherches Médicales" which made available to me, progressively, research space. It is within this buirding that Nestle S.A. (Vevey) constructed for our group an excellent animal quarter. Our gratefulness to this company for its scientific and financial support is immense, all the more that it has always respected our academic freedom, a remarkable trait indeed. In 1970, our group consisted of five persons; now the number is $20-24$. The challenge over the years was to create an entirely new research group, at a time when the oil crisis, and the money problem derived from it, was starting. The acknowledgements at the end of the present article give an idea of the many institutions which supported us financially and complemented the official State budget which tends, as money gets scarce, to finance teaching and administration more than research.

My research was collaborative: it involved many persons to whom I am greatly indebted. The overall strategy chosen was to study the regulation of insulin target tissues in normal and obese rodents, in an attempt to understand a possible primary aetiology of obesity syndromes and their relationship to Type 2 diabetes.

We started by setting up (Dr. F. AssimacopoulosJeannet in collaboration with Dr.J.H.Exton, who was invited professor in Geneva) a technique to perfuse livers from normal mice. This was a novelty as all scientists were working, at that time, with perfused rat livers. Mouse liver weight is about $1.2 \mathrm{~g}$ while rat liver weight is $12 \mathrm{~g}$, a substantial difference when it comes to perfusing the organ. As you can see from Figure 1, perfused livers from normal mice responded well to glucagon, epinephrine and cAMP [2]. In these perfused mouse livers we investigated many aspects of the normal liver, in particular the role microtubules and microfilaments play in protein and lipoprotein secretion [3-8]. Dr. Y. Le Marchand-Brustel played a key role in this work as she did, together with Dr.F. Assimacopoulos-Jeannet, Dr.E. G. Loten and others, in the initial studies of obesity syndromes. I shall not summarize our data pertaining

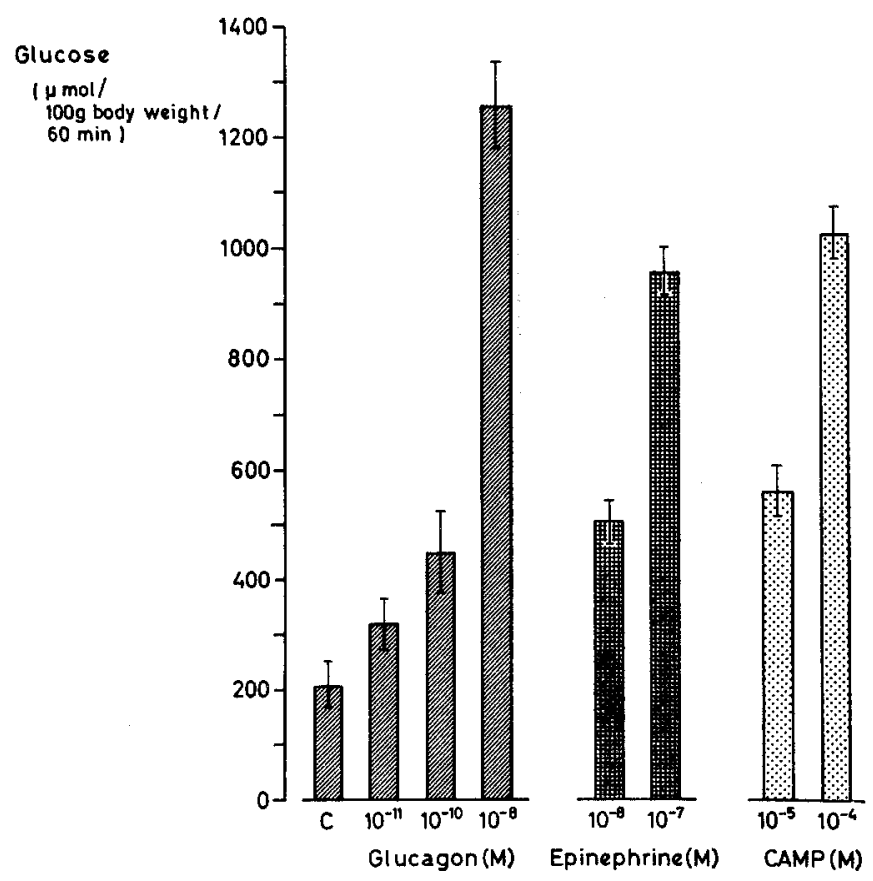

Fig. 1. Effect of glucagon, epinephrine and cyclic AMP on glycogenolysis of perfused livers of fed normal mice. Mean of 4 experiments \pm SEM [2] 
to the normal regulation of insulin target tissues as I will concentrate on the pathophysiological aspects of our research effort.

We chose to perfuse the liver of the normal mouse because we wanted to investigate subsequently livers of genetically obese animals. At that time the animal model most easily available was the $o b / o b$ mouse, and its metabolism had been little studied. We found that perfused livers of genetically obese $(o b / o b)$ mice had the following abnormalities (Fig. 2): (a) their lipogenesis

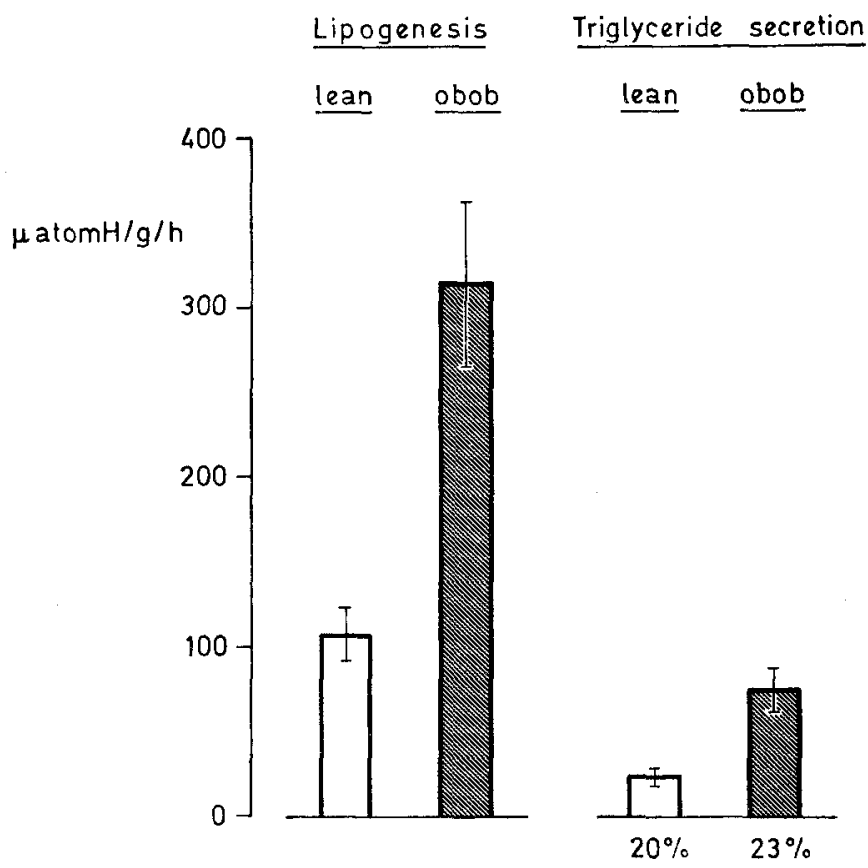

Fig. 2. Lipogenesis and triglyceride secretion by perfused livers of fed lean and obese $(o b / o b)$ mice. Lipogenesis was measured in the presence of glucose $(11 \mathrm{mmol} / \mathrm{l})$ by incorporation of tritium, from ${ }^{3} \mathrm{H}_{2} \mathrm{O}$, into total (liver + perfusate) triglyceride fatty acids. Triglyceride secretion refers to release of newly synthetized (i.e. tritium labelled) triglycerides. Percentages relate triglyceride secretion to lipogenesis. Means of 4 experiments \pm SEM [9] was greatly enhanced compared with controls; (b) they oversecreted triglycerides as VLDL; (c) the percentage of VLDL secreted was the same in livers of both lean and obese mice, thus providing an explanation as to why the hepatic parenchyma of obese animals was infiltrated with fat [9]. We also observed, as shown by Figure 3 , that the same abnormalities were seen in perfused livers from ventromedial hypothalamic $(\mathrm{VMH})$-lesioned animals $[10,11]$. It also appeared that over-synthesis of lipids in $o b / o b$ mice was not restricted to the liver but was present in adipose tissue as well (Fig.4) [12]. This also turned out to be true for adipose tissue obtained from mice rendered obese via hypothalamic lesions (Fig. 8 A) [13].

We thus began to think that a common pathology was somehow linking genetic and hypothalamic obesity syndromes. We were struck by the observation that both types of obese animals had high basal plasma insulin levels (e.g.genetically obese $o b / o b$ mice: $5-25 \mathrm{ng} / \mathrm{ml}$; hypothalamic obese mice: $7-15 \mathrm{ng} / \mathrm{ml}$, at the age of 8-15 weeks). We then hypothesized that livers and adi-

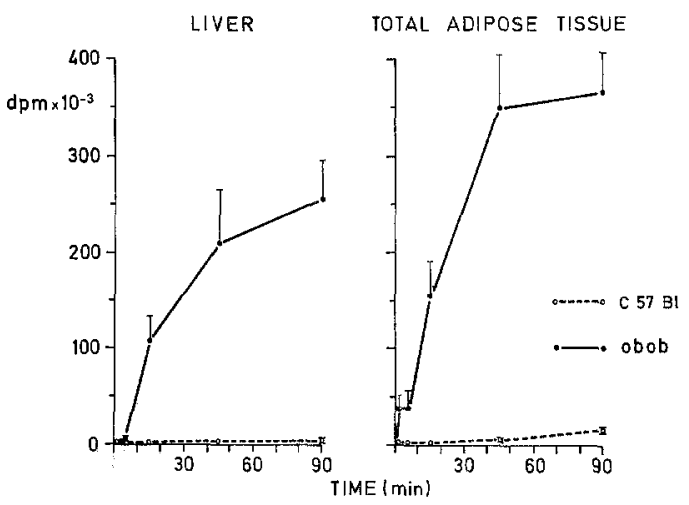

Fig.4. Incorporation of radioactivity into triglycerides of liver and adipose tissue of lean $(\mathrm{O}----\mathrm{O})$ and obese $(a b / o b,-0)$ mice in vivo following an intravenous administration of $\mathrm{U}-{ }^{14} \mathrm{C}-\mathrm{D}$ glucose. Means of 6 experiments 1 SEM [12]
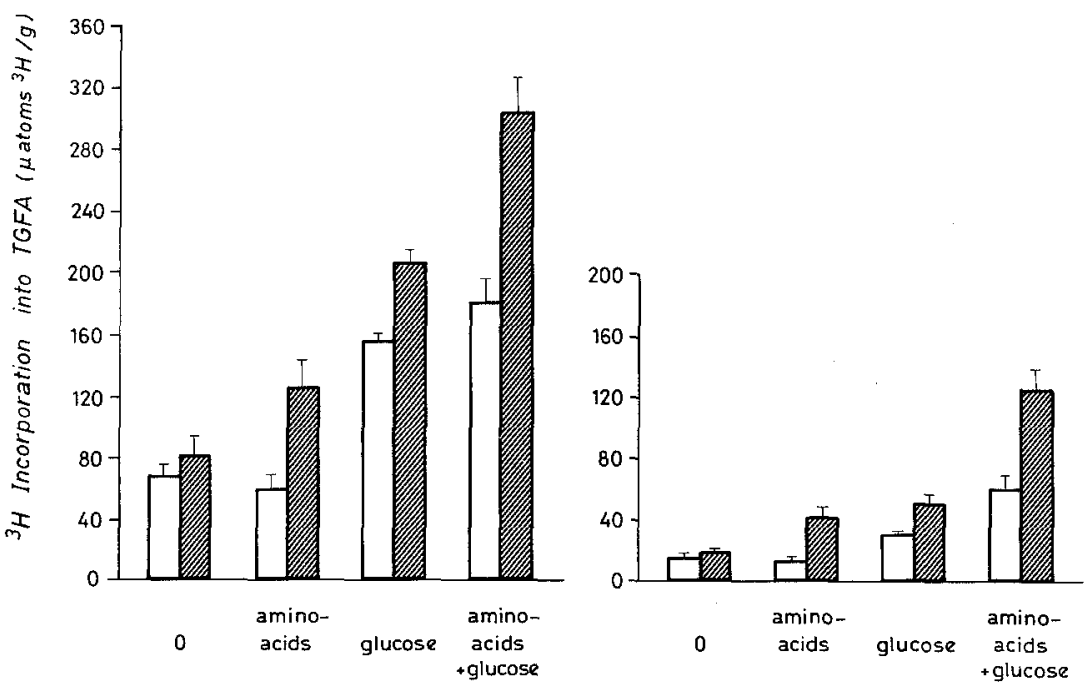

Fig. 3. Left hand panel: Total lipogenesis (incorporation of tritium from ${ }^{3} \mathrm{H}_{2} \mathrm{O}$ into triglycerides). Right hand panel: Secretion of newly synthetized triglycerides (tritium labeled) by perfused livers of fed controls $(\square)$ and VMH-lesioned $(\mathbb{S})$ rats fed a restricted diet matching that of controls. Means of 6 experiments mSEM [10] 


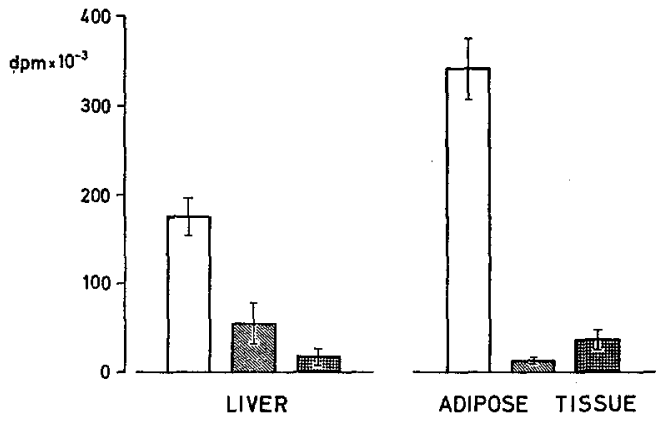

Fig.5. Effect of streptozotocin treatment or of anti-insulin serum administration on the incorporation of radioactivity in triglycerides of liver and adipose tissue of obese hyperglycemic $(o b / o b)$ mice following an intravenous dose of $\mathrm{U}-{ }^{14} \mathrm{C}-\mathrm{D}$ glucose given in vivo. Measurements made after $90 \mathrm{~min}$. $\square$ Non-treated; $\mathbb{\mathbb { s }}$ streptozotocin-treated; 葍 anti-insulin serum-treated. Means of 6-12 experiments \pm SEM [12]

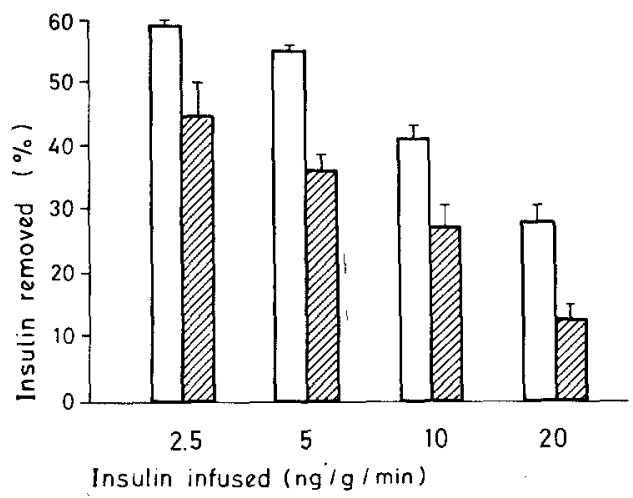

Fig.6. Effect of increasing concentrations of insulin infused into the portal vein upon its removal by perfused livers of fed lean (open bars) and obese $(o b / o b)$ (hatched bars) mice. Insulin removal was determined at the steady state and expressed as percent of insulin infused into the portal vein. Means of at least 4 experiments \pm SEM [17]

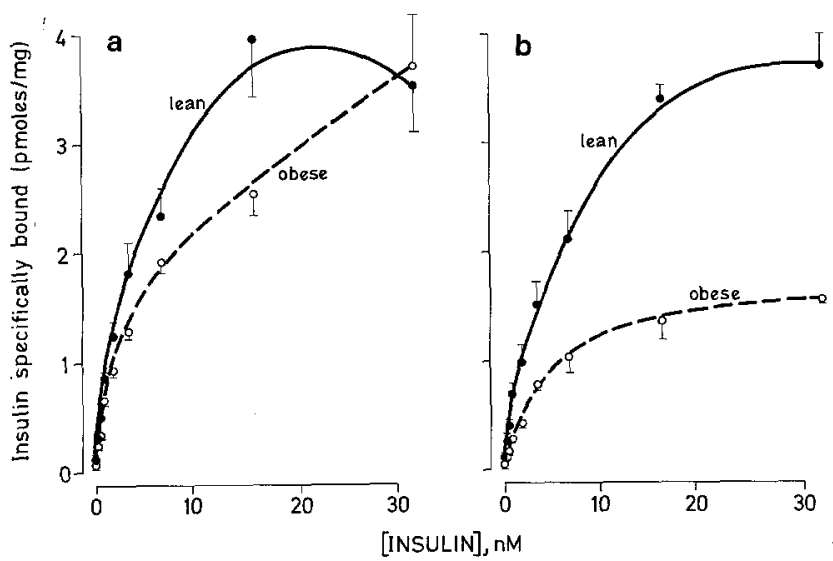

Fig. 7 a and b. Specific binding of insulin to liver plasma membranes from lean and hypothalamic-obese mice. a 9-week-old mice. b 20 -week-old mice. Note that 9 weeks of age refers, for the animals lesioned in the hypothalamic area, to animals studied 6 weeks after gold-thio-glucose (GTG) administration; 20 weeks of age refers to animals studied 13-17 weeks after GTG administration. Basal insulinemia of group A: lean $=2.6$, obese $7.3 \mathrm{ng} / \mathrm{ml}$; of group B: lean $/ 2.2$, obese $15.2 \mathrm{ng} / \mathrm{ml}$. Means of 4 experiments \pm SEM [13]

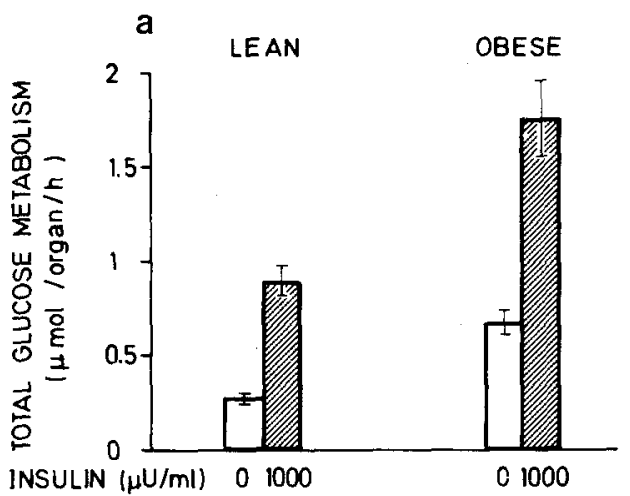

b

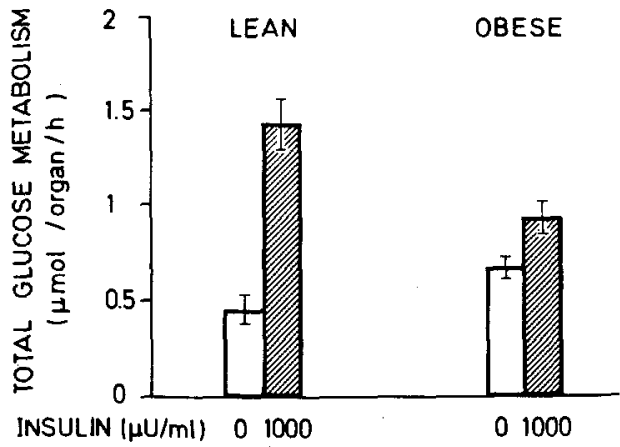

Fig. 8 a and b. Effect of insulin on glucose metabolism by epididymal adipose tissue of lean and hypothalamic-obese mice. a 9-week-old mice. b 20-week-old mice. Hypothalamic lesions were carried out as indicated in Figure 7. U- ${ }^{14} \mathrm{C}$ D-glucose in the medium at the final concentration of $7.5 \mathrm{mM}$. Means of 9-12 experiments \pm SEM [13]

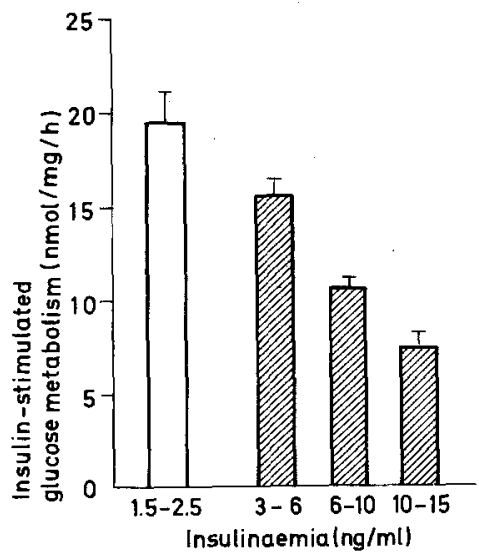

Fig. 9 Correlation between in vivo basal plasma insulin levels before experiments and in vitro responses of soleus muscles to insulin in lean (open bars) and hypothalamic-obese (hatched bars) mice. Hypothalamic lesions were carried out as indicated in Fig. 7. Means of 5-12 experiments \pm SEM [13]

pose tissue of obese animals were basically normal, but were probably overstimulated by their prevailing hyperinsulinemia. To show this we treated obese animals with streptozotocin (6-10 days prior to the experiment) or, acutely, with anti-insulin serum. As illustrated by Figure 5, such treatments restored the increased liver and adipose tissue lipogenesis of the obese animals to nor- 


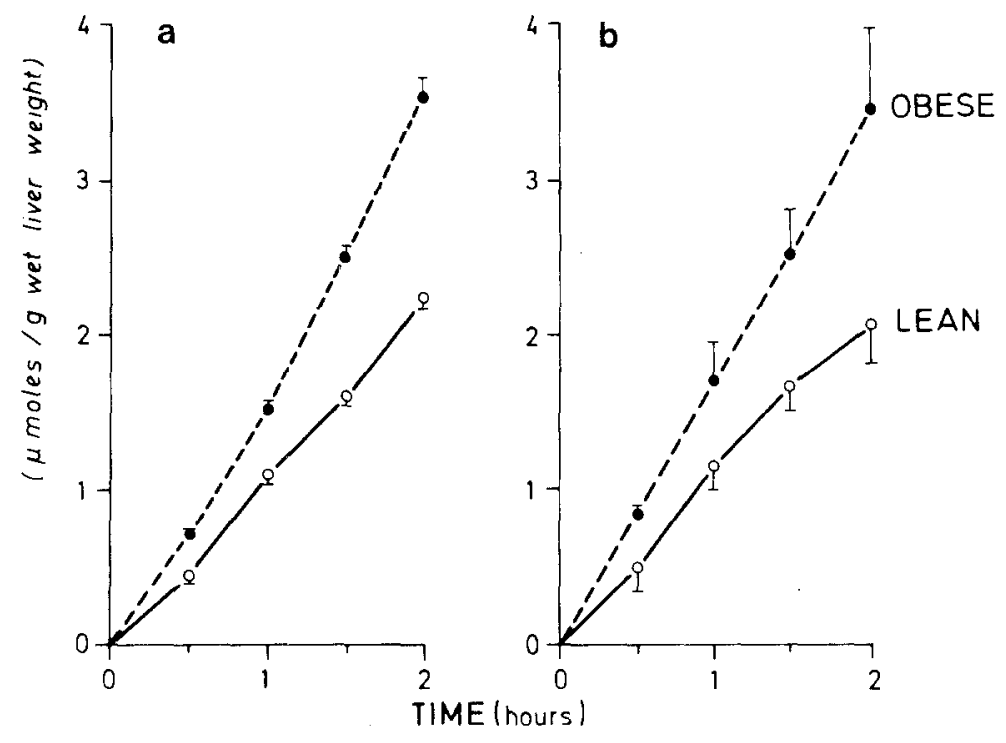

Fig. 10a and b. Secretion of unlabelled triglycerides by perfused livers of normal $(O-O)$ and hypothalamic obese (-_- ) mice. a 9-week-old mice. b 20-week-old mice. Hypothalamic lesions were carried out as indicated in Figure 7. Means of 8 experiments \pm SEM [13]

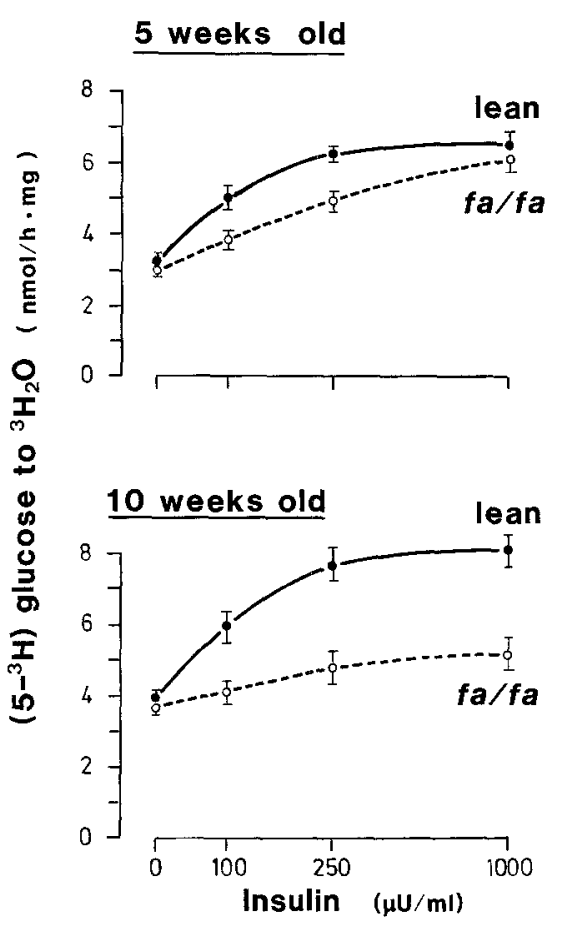

Fig. 11. Insulin effect on glucose metabolism via glycolysis (as measured by the production of ${ }^{3} \mathrm{H}_{2} \mathrm{O}$ from $5 \mathrm{mM}-\left[5^{3} \mathrm{H}\right]$ glucose) in strips of soleus muscles from lean $(-)$ ) and genetically obese $(f a / f a$, O----O) rats at the age indicated. Means of 8 experiments \pm SEM [30]

mal $[9,12]$. This was accompanied, in adipose tissue, by a dramatic decrease in the activities of fatty acid synthetase and acetyl CoA carboxylase [14], and in perfused livers by a normalization of the high VLDL output, as well as of the low ketogenesis [9].

It is of importance to emphasize that streptozotocin treatment did not make genetically obese mice insulindeficient. Basal insulinemia was decreased from, for instance, $7-25 \mathrm{ng} / \mathrm{ml}$, to about $2-3 \mathrm{ng} / \mathrm{ml}$, still severalfold higher than normal $[9,12,14]$. Such treatment prob-

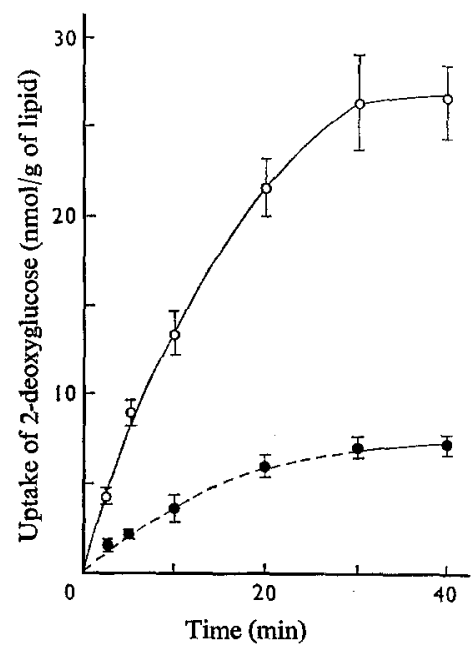

Fig. 12. Effect of cytochalasin B on uptake of 2-deoxyglucose by isolated fat cells. $0.1 \mathrm{mM}$ 2-deoxyglucose $\left[1-{ }^{3} \mathrm{H}\right]$ glucose. Control: $(\mathrm{O}-\mathrm{O})$; cytochalasin $(2 \mu \mathrm{g} / \mathrm{ml} \longrightarrow$ ). Means of 5 experiments \pm SEM [31]

ably just made the obese animals unable to oversecrete insulin and thus unable to overstimulate target tissues. The same findings were obtained (Fig. 5) with obese rodents which were acutely treated with anti-insulin antibodies $[10,12]$.

We therefore came to the conclusion that hyperinsulinemia was probably a key factor in bringing about the obesity in the syndromes just mentioned. We started thinking that insulin oversecretion, as it was present both in genetic obesity (in which Central Nervous System (CNS) defects, albeit unrelated to the regulation of insulin, had been described) $[15,16]$ and in obesity provoked by lesions of the hypothalamic area, might find its origin within the CNS. We realized that hyperinsulinemia was a defect placing obese rodents in a series of vicious circles that prevented them ever regaining a nor- 
PLASMA MEMBRANES
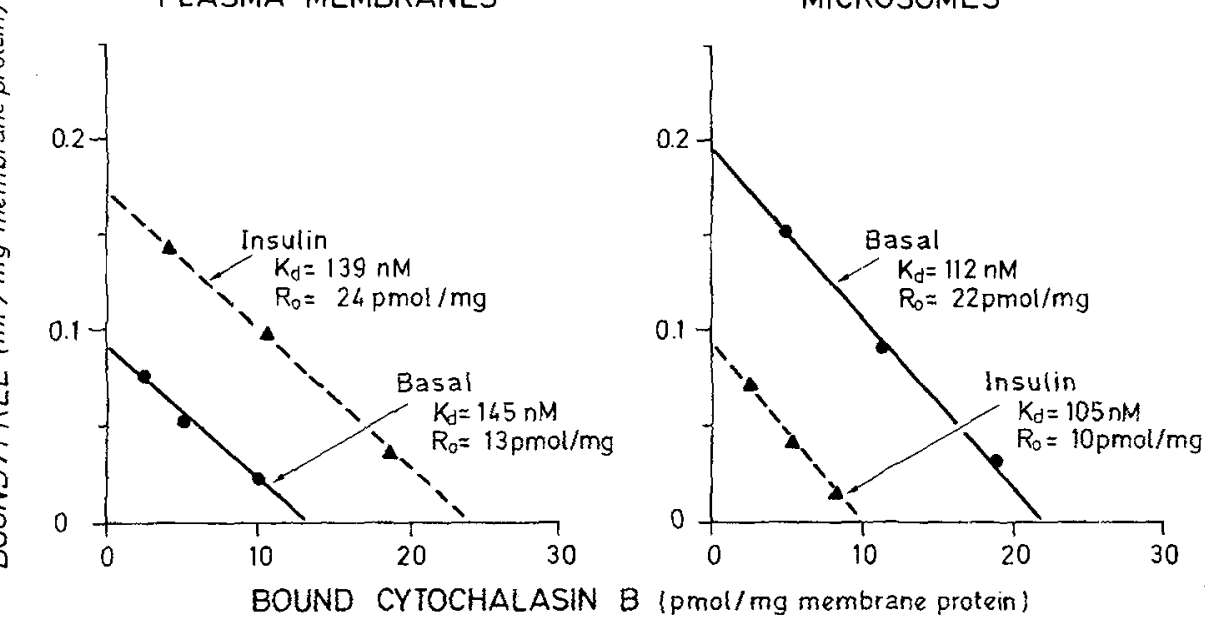

Fig. 13. Scatchard analysis of equilibrium $\left[{ }^{3} \mathrm{H}\right]$ cytochalasin $\mathrm{B}$ binding to isolated rat diaphragm plasma and microsomal fraction at $4^{\circ} \mathrm{C}$. Prior to preparing, these fraction intact diaphragms were incubated at $37^{\circ} \mathrm{C}$ in the absence $(C-O)$ or presence $(\Delta \cdots \Delta)$ of

$280 \mathrm{nM}$ insulin. Cytochalasin $\mathrm{B}$ binding was then measured at the cytochalasin $B$ concentration indicated in the presence or absence of $400 \mathrm{mM} \mathrm{D}$-glucose (displacement of cytochalasin by glucose being a measure of specific glucose transport units). $K_{d}=$ dissociation constant in $\mathrm{nM}, \mathrm{R}_{\mathrm{o}}=\mathrm{D}$-glucose inhibitable cytochalasin $\mathrm{B}$ binding sites in $\mathrm{pmol} / \mathrm{mg}$ membrane protein. Means \pm SEM of duplicate determinations. The data indicate the existence of a translocation of glucose transport units from the cell interior to the plasma membrane under the infiuence of insulin $[34,35]$

\section{EARLY ABNORMALITIES}

1 Insulınemia 4

2. Glucose : $N$ or

3. R number : $N$

(4)

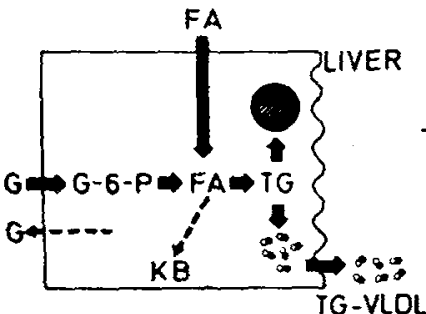

\section{LATER ABNORMALITIES}

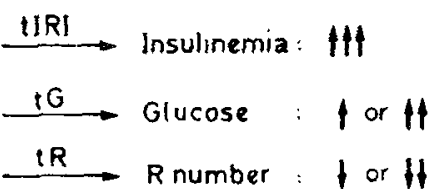

(5)

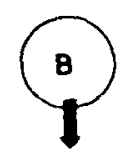

HYPERINSULINEMIA

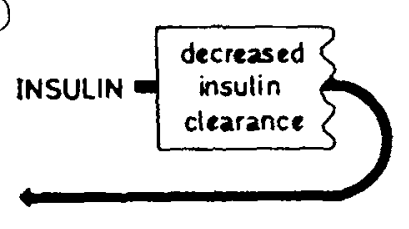

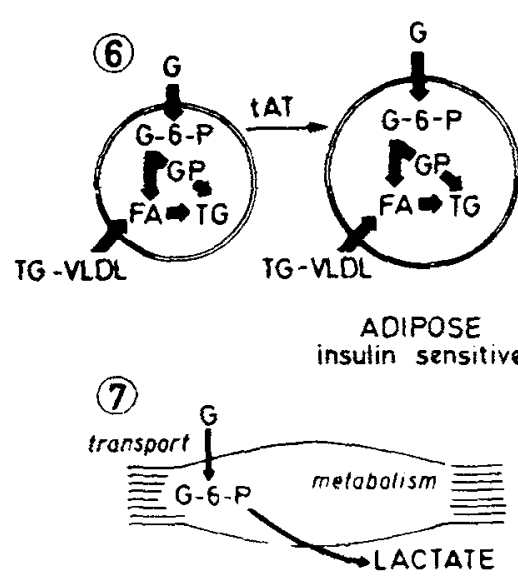
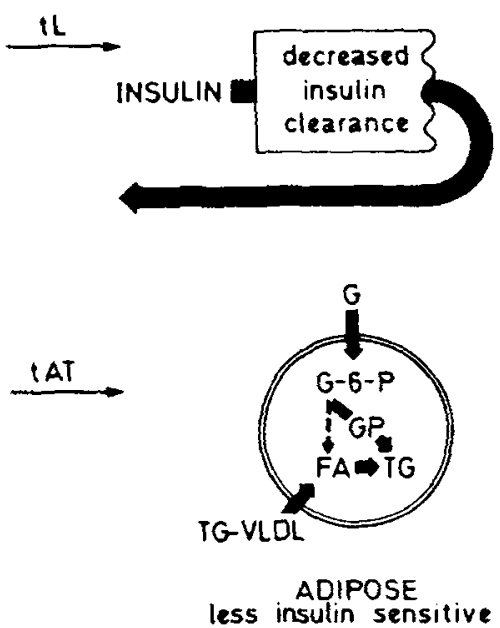

MUSCLE: insulin sensitive

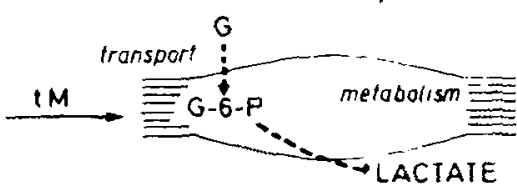

MUSCLE : less insulin sensitive and/or responsive
Fig. 14. Schematic representation of the progressive appearance of abnormalities in animal obesity syndromes. The duration $(t)$ needed to lead insulinemia (IRI), glycemia (G), insulin receptor number of target tissues $(R)$, liver $(L)$, adipose tissue (AT), and muscle (M) to their final pathological state is quite variable. Hyperinsulinemia is one of the earliest abnormalities detected, and probably plays a major role in producing most of the abnormalities depicted here. Muscle is the tissue which evolves most rapidly toward an insulin resistant state. Ultimately all metabolic pathways of glucose in muscle become less insulin-sensitive and responsive. Heavy arrows (except in 5) indicate pathways that are increased, dotted ones pathways that are decreased when compared to normal controls. $\mathrm{G}=$ Glucose; $\mathrm{FA}=$ Fatty acids; $\mathrm{KB}=\mathrm{Ke}$ tone bodies; TG = Triglycerides; VLDL = very low density lipoproteins [36] 


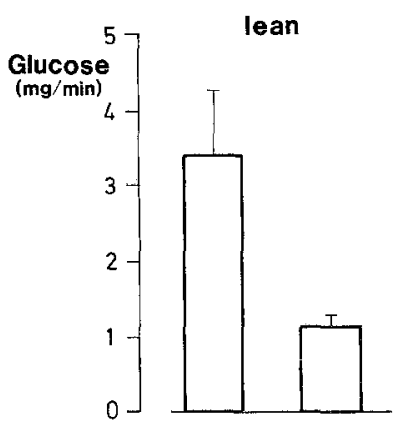

obese (fa/fa)
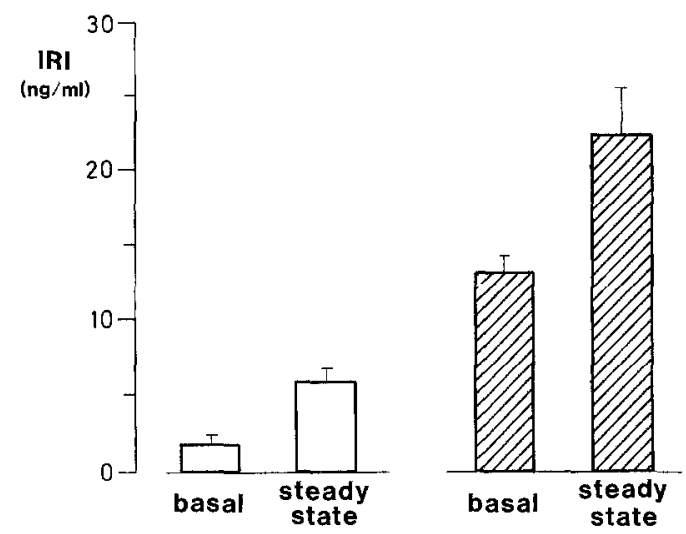

Fig. 15. In vivo measurement of hepatic glucose production under low (basal) and high (steady-state) levels of insulin produced by insulin infusion in 10-11 week-old freely moving (i. e. unanaesthetized) lean (open bars) and genetically obese (hatched bars) ( $f a / f a)$ rats (euglycemic clamp technique). Upper panel: glucose refers to hepatic glucose production measured during the euglycemic clamps. Lower panel: corresponding plasma insulin values for respective groups. Each bar, mean of 4-5 Experiments \pm SEM [37]

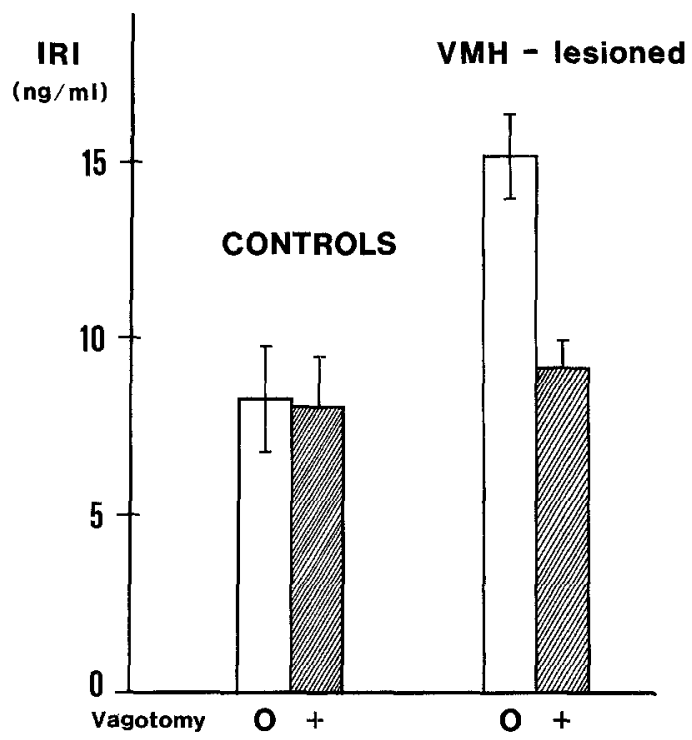

Fig. 16. Effect of acute lesions of the ventromedial hypothalamic (VMH) area on glucose-induced insulin output in anaesthetized rats and of acute bilateral subdiaphragmatic vagotomy. Open bars represent plasma insulin levels $10 \mathrm{~min}$ after control (cortex lesions) or VMH lesions. Hatched bars represent plasma insulin levels $10 \mathrm{~min}$ after vagotomy of control or VMH-lesioned rats. Means of 6 experiments \pm SEM $[42,43]$ mal body weight. One example of this is given in Figure 6: as can be observed, the ability of the liver to clear insulin was decreased in genetically obese $(o b / o b)$ mice and rats $(f a / f a)$ compared to that of lean controls [17, 18]. This indicated that oversecretion of insulin made hyperinsulinemia worse as it partly prevented normal degradation of the hormone.

By 1976 there were debates about the cause, or at least about the cause-effect relationships, of the various defects observed in obesity syndromes. Some thought that hyperinsulinemia was important; others were proposing that it was not important - they often measured basal, and not substrate-induced insulin output. Others suggested that insulin resistance was a primary event that would produce (via increasing blood sugar) insulin oversecretion [19]. As summarized above we could not think that insulin resistance was an early event in our animal models, in view of the observed overstimulation of metabolic pathways. In an attempt to clarify the sequence of events occurring in obesity, we carried out longitudinal studies summarized in Figure 7-10 [13]. We first used hypothalamic obesity (gold-thio-glucose, (GTG)-treated mice) to observe: (a) that down-regulation of insulin receptor numbers took time to occur, and was seen only when insulinemia was increasing to rather high basal values (Fig. 7); (b) that target tissues (taking the particular example of adipose tissue) were, in the initial phase of the syndrome, over-responsive to insulin (Fig. $8 \mathrm{a}$ ) and became insulin-resistant only at a later stage (Fig. $8 \mathrm{~b}$ ). This evolution was again observed in both genetic as well as in hypothalamic obesities [13, 20]. Such initial overstimulation and subsequent insulin resistance was later shown (in VMH-lesioned rats studied by euglycemic clamps) to prevail not only in liver and adipose tissue, but in the muscle mass as well [21]; (c) we also observed that muscle insulin resistance was well correlated with the degree of hyperinsulinemia prevailing at the time of the experiment, i.e. at the time when the (soleus) muscle was removed and incubated. This is shown in Figure 9 and suggests that hyperinsulinemia could well be a driving force not only for the occurence of obesity but for that of insulin resistance [13]. Of note is the fact that some pathways do not become insulin resistant. Thus, as illustrated by Figure 10 , VLDL output (as well as lipid synthesis, not shown) by perfused livers of hypothalamic obese mice always remains higher than normal. This observation holds true for most animal models of obesity as does the finding that adipose tissue lipoprotein lipase activity usually remains high in obese rodents [22]. Thus, despite the occurrence of insulin resistance, some pathways (usually involved in fat deposition) remain overactive, thereby maintaining the state of obesity. An explanation has recently been proposed for the lack of insulin resistance in liver lipogenesis: under basal conditions the hepatocytes of genetically obese $(f a / f a)$ rats are characterized by increases in fructose 2,6-bisphosphate and glycerol 3-phosphate concentrations as well as in pyruvate 
kinase activity. This would suggest a continuous stimulation of glycolysis, with channeling of glucose-carbon into lipids [22, 23, 24]. In fact in appears from our recent work that fed lean rats infused with insulin, as studied in vivo by a euglycemic clamp, may have similar stimulation of glycolysis and of lipogenesis as fed obese animals chronically exposed to their high basal insulinemia $[22,23,25]$.

Our results have shown that muscles of obese rodents become insulin-resistant, a resistance characterized by decreased insulin receptor number, decreased insulin sensitivity and decreased responsiveness of pathways of glucose metabolism [26-29]. It is of interest to note that the severity of muscle insulin resistance increases with the duration of the syndrome, as summarized by Figure 11. In this work muscles of normal and genetically obese $(f a / f a)$ rats were studied using a technique of incubating strips of soleus muscles with their tendons. This method allows the preparation of four muscle strips from the same animal and avoids the problem of substrate diffusion [30]. Figure 11 (upper panel) shows that, at the beginning of the obesity syndrome (when hyperinsulinemia is still relatively moderate), glycolysis in muscles from obese animals is less insulin-sensitive than controls, an abnormality that is the consequence of decreased insulin receptor numbers. Later on (Fig. 11, lower panel) the muscles of the obese rats become not only less insulin-sensitive but also less insulin-responsive (poor response to insulin even at supramaximal concentrations). The latter abnormality can be accounted for only by post-insulin binding alterations. It was subsequently shown [28-30] that those post-insulin binding defects of muscles from obese rodents include a decrease in glucose transport per se [29] and an increase in the utilization of endogenous lipids which, by increasing intracellular citrate concentrations, inhibits the glycolytic pathway at the phosphofructokinase level [30]. Increased endogenous fat utilization could be secondary to the lack of availability of energy from glucose-carbon. The latter defect could be due to an altered glucose transport system. We described several years ago and, as depicted by Figure 12, that glucose transport was inhibited by cytochalasin B [31]. This field remained dormant until two independent groups [32, 33], one of them using cytochalasin B as a marker of the glucose transport system [32], demonstrated in adipose tissue, that insulin rapidly, specifically and reversibly produced a translocation of glucose transporters from an intracellular membrane pool to the plasma membrane. We have adapted this technique to other tissues, in particular to muscle $[34,35]$. As illustrated in Figure 13 we have confirmed that in muscle (diaphragm) a similar system of translocation of glucose transporters prevails and that, when exposed to insulin, the number of glucose transporters at the plasma membrane increases while that of the microsomal pool decreases, the total number of glucose transporters remaining unchanged [34]. Work is now being carried out
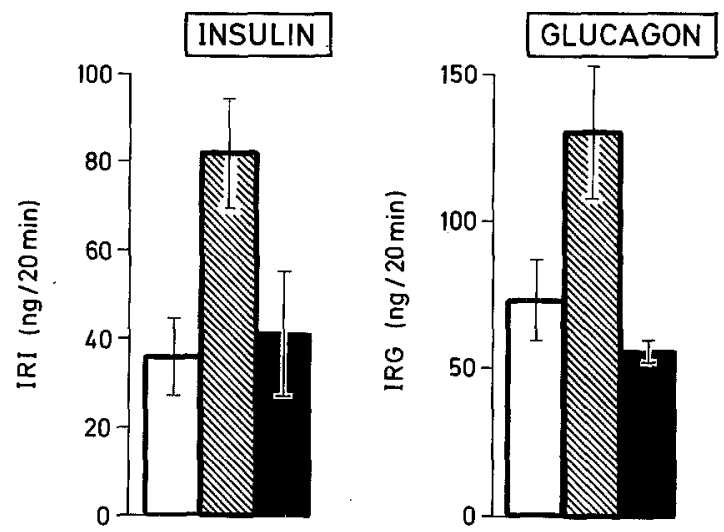

Fig. 17. Effect of arginine on insulin and glucagon secretion by perfused pancreases of control and food-restricted ventromedial hypothalamic (VMH)-lesioned rats and reversal of these abnormalities by superimposed infusion of atropine $(25 \mu \mathrm{mol} / 1)$. $\square$ Controls;

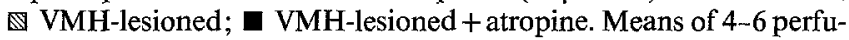
sions \pm SEM $[50]$

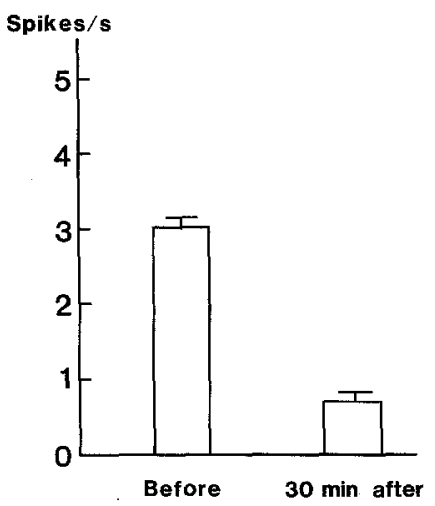

Fig. 18. Spontaneous electrical activity of filaments of efferent sympathetic nerves of interscapular brown adipose tissue before and $30 \mathrm{~min}$ after acute lesions of the ventromedial hypothalamus (VMH) in anaesthetized rats. Measures of initial activity (i.e. before) and of activity $30 \mathrm{~min}$ after VMH lesions were carried out with the same rat. Means of 5 experiments \pm SEM [52] $p<0.001$

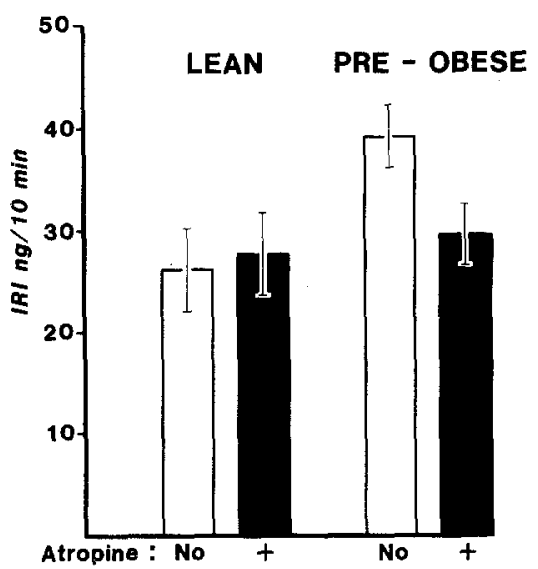

Fig. 19. Glucose-induced insulin secretion (represented as surface area per 10 after $\mathrm{i}-\mathrm{v}$ glucose bolus injection, $300 \mathrm{mg} / \mathrm{kg}$ body wt) in lean Zucker and pre-obese Zucker $(f a / f a)$ rats with our without acute atropine $(5 \mathrm{mg} / \mathrm{mg} \mathrm{i}-\mathrm{v})$ pretreatment. Pre-weaned animals, aged 17 days. Each column shows mean of 5-9 experiments \pm SEM $[57,58]$ 


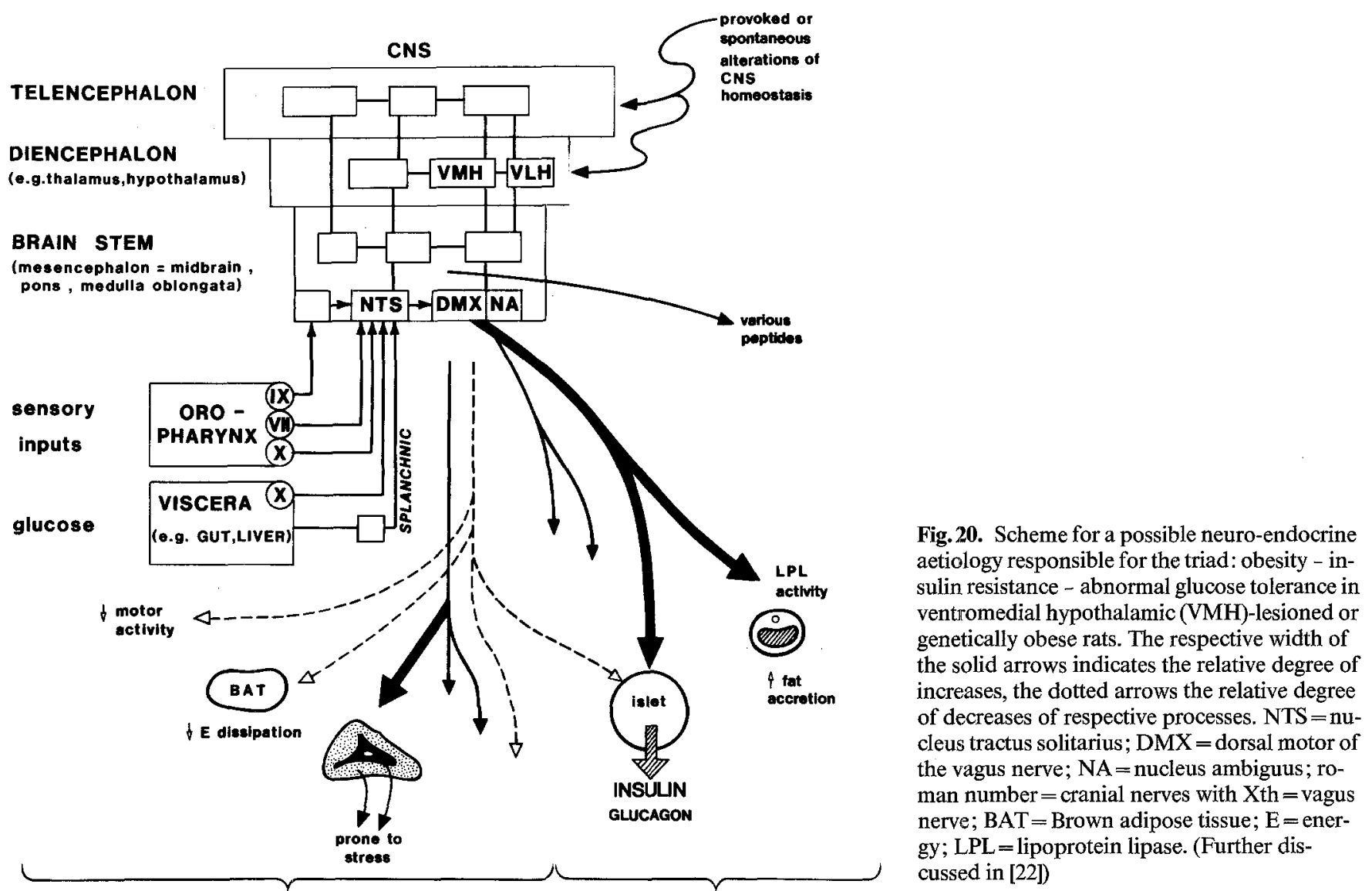

sympathetic efferences

parasympathetic efferences

to attempt to determine whether and how the system of the glucose transport units is abnormal in muscles as well as in brown adipose tissue of obese rodents (D. Zaninetti and R. M. Greco, unpublished data).

The simplest way to summarize our views about the evolution of the obesity syndrome is to consider Figure 14 [36]. The studies summarized by this figure have been and still are being extended by the use of two techniques which we have set up for small rodents: (a) the eu- and hyperglycemic clamp techniques that enable us to study hepatic glucose production and overall glucose metabolism in vivo under steady-state conditions [37]; and (b) the use of non-steady-state kinetics (double tracer technique) to measure hepatic glucose production and overall glucose metabolism in conscious, freely moving rats, during the spontaneous ingestion of a glucose-meal [38]. For example, and as can be seen from Figure 15, the euglycemic clamp technique enabled us for the first time to detect an in vivo defect in glucose production by the livers of genetically obese $(f a / f a)$ rats in which the high basal or induced increases in plasma insulin levels are unable to shut off hepatic glucose production [37]. Full dose responses of insulin (using the euglycemic clamps) allowed us recently to demonstrate severe in vivo insulin resistance of peripheral glucose utilization (mostly muscle mass) in the $f a / f a$ rats [39]. Similarly, using the same technique, we have shown that the process of hepatic glucose production in the $f a / f a$ obese rats can be shut off only when insulin is used at the pharmacological concentrations of about $20,000 \mathrm{mU} / 1$ [39]. Here again using the clamp techniques, analogous data have been observed in VMH-lesioned obese rodents [21]. The underlying mechanisms of this defect in hepatic glucose production are as yet unclear. For instance, it could be a combination of intrinsic hepatic abnormalities such as the inability of obese rodents to inhibit phosphorylase $a$ due to its sustained activation via high cytosolic $\mathrm{Ca}^{++}$that would stimulate phosphorylase kinase $[22,40,41]$, as well as to the presence of catabolic hormones (glucagon, glucocorticoids) that would be insufficiently counteracted by insulin in vivo [21, 22, 39]. Recently it has been shown (using non-steady-state kinetics) that conscious, freelymoving, genetically obese $(f a / f a)$ rats are unable, during the spontaneous ingestion of a glucose-meal, to inhibit hepatic glucose production and that this abnormality is the likely explanation for their abnormal oral glucose tolerance described below (F. Rohner-Jeanrenaud, J.Proietto and E. Ionescu, unpublished data.).

As mentioned above, we place great emphasis upon oversecretion of insulin as we think that in both VMHlesioned and genetically obese $(f a / f a)$ rats, it may be one of the main aetiological factors that appears to relate to a series of CNS disorders. When surveying the 
literature and our own data, it is rather evident that hypersecretion of insulin is responsible for initially inducing obesity and that, provided hyperinsulinemia is present, hyperphagia is not necessary but acts only as an amplification factor $[19,22]$. We were of course aware of the many data showing that lesions of the hypothalamus resulted in high plasma insulin levels $[19,22]$. The question we posed was how rapidly the increased insulin output would occur after VMH lesions. The data are summarized in Figure 16. One can see that, within $10 \mathrm{~min}$ following lesions of the VMH area of normal anaesthetized rats, substrate (glucose)-induced insulin output is increased $[42,43]$. This change is mediated via the vagus nerve as it can be completely and rapidly reversed by a superimposed vagotomy [43]. Thus, as described in details elsewhere [44], we propose that acute VMH lesions produce rapid disturbances of the CNS homeostasis that result, via unknown mechanisms, in a stimulation of the motor neurons of the vagus in the brain stem, producing increased efferent parasympathetic activity. These motor neurons linked to the endocrine pancreas have been shown to lie within the mid part of the dorsal motor nucleus of the vagus nerve (DMX) and in the nucleus ambiguus (NA) [45-47]. The alteration of efferent parasympathetic pathways following VMH lesions is all the more striking since, in normal rats, the efferent vagus that reaches the pancreas is under a powerful tonic GABA inhibitory action, probably to prevent hypoglycemia [48]. The parasympathetic origin of the disturbance produced by VMH lesions is further substantiated by the observation that not only insulin but also glucagon secretion is augmented following VMH lesions, an atropine-inhibitible defect (Fig. 17) [49-51]. The increased insulin output following VMH lesions occurs rapidly enough to make it a likely candidate as the cause of subsequent stimulation of lipogenic pathways. Furthermore the accompanying increase in glucagon output is one of the reason why, even prior to the development of insulin resistance, VMH-lesioned rats are never hypoglycaemic.

Thus obesity may be viewed as a neuroendocrine disorder. This concept has been strengthened by recent data bearing on the study not of parasympathetic but of the sympathetic outflow. In this work, normal rats were anaesthetized and placed on a stereotaxic frame. The spontaneous activity of a purely sympathetic nerve was studied by electrophysiological means and, for convenience, the sympathetic nerve reaching the interscapular brown fat was selected. The nerve was cut and the electrode placed on the proximal end of the cut nerve, thereby enabling a recording of only efferent nerve activity [52]. As can be seen by Figure 18, electrolytic lesions of the VMH area resulted in a marked and rapid (within $30 \mathrm{~min}$ ) decrease in the efferent sympathetic outflow. This certainly has influence on the occurrence and maintenance of obesity by preventing heat dissipation mechanism(s). Indeed it was shown, in collaboration with the Department of Physiology of Geneva, that brown adipose tissue of both genetically and $\mathrm{VMH}$ lesioned obese rodents lost their ability to oxidize fat in response to the electrical stimulation of their sympathetic nerves or to other stimuli [53-56]. Decreased sympathetic outflow could also play a role (if it were also to exist at the level of the endocrine pancreas) in reinforcing hyperinsulinemia as it would remove the usual inhibitory effect of the sympathetic system on the B cell.

The potential physiopathological relevance of studying VMH-lesioned rats would be little if the changes observed were restricted to a syndrome that is artificially produced. This is however not the case; similar changes appear to occur in the genetically obese ( $\mathrm{fa}$ / $f a)$ rats. Small pups that will grow subsequently to become normal or obese rats have been studied recently with regard to the secretory activity of their endocrine pancreas. Unweaned (17-day-old) pups have been thus investigated prior to the occurrence of obesity, at a time when they are indistinguishable from each other, have the same body weight and normal basal insulinemia. After testing with an IV challenge with glucose or arginine all pups are placed back with their mother, subsequently weaned and kept until some of them $(25 \%$, as we deal with a recessive gene) become obese. The obese rats are retrospectively referred to as pre-obese [57, 58]. Figure 19 shows that genetically pre-obese pups do oversecrete insulin in response to glucose (or arginine) compared to the pups that remain lean. Moreover, the insulin oversecretion of the pre-obese animals is, when arginine is used as substrate, accompanied by glucagon oversecretion. This double hormonal secretory defect is mediated by the efferent vagus as it can be inhibited by acute atropine adiminstration $[57,58]$. Thus one can hypothetize that, in the genetically pre-obese $(f a / f a)$, a pathological situation analogous to that produced by acute VMH lesions prevails. Firstly insulin oversecretion is an early abnormality, that can therefore be causal in the aetiology of obesity. Secondly insulin and glucagon hypersecretion is an abnormality that is related to CNS-borne increase in the efferent vagus tone reaching the pancreas. One should stress that other investigators have found that noradrenaline turnover, at the level of the pancreas and of brown adipose tissue, is decreased in genetically obese rats [22]. Moreover the ability to dissipate energy as heat (a sympathetic nerve mediated process in normal animals) is decreased early in the evolution of the syndrome, i.e. in genetically pre-obese pups [22].

These data are in keeping with the view that, in genetically obese rodents, increased parasympathetic efferent activity is accompanied by decreased sympathetic activity. This view is schematized in Figure 20 and is justified in more detail elsewhere [22, 44]. We consider that at least some types of spontaneous obesities could be the result of a neuro-endocrine pathology with the metabolic consequences indicated in the figure. If such a mechanism underlies some types of human obesity, it should explain why treatment is usually unsuccessful 


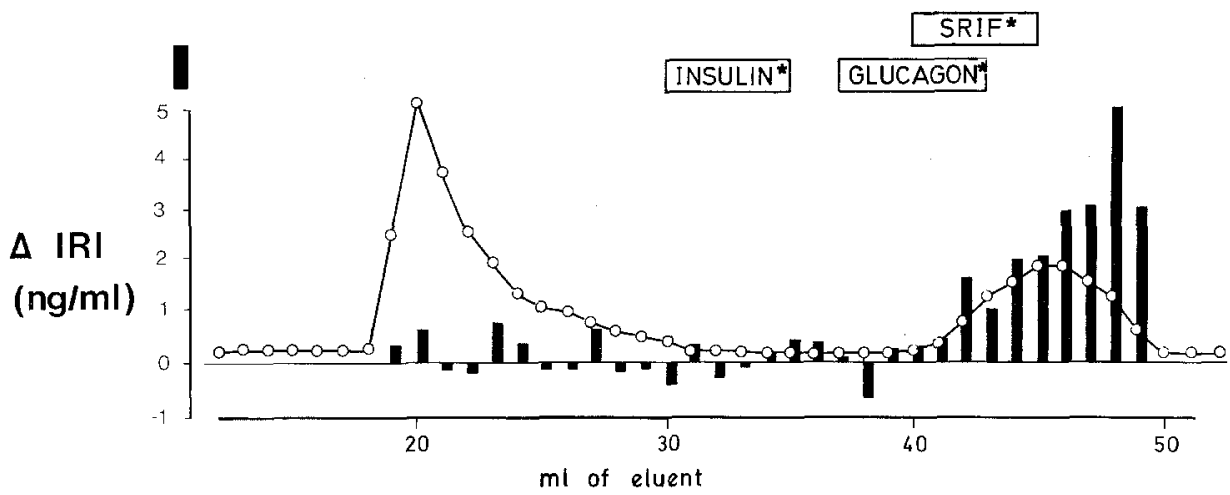

Fig. 21. Changes in plasma insulin (solid bars) from baseline values after injection to normal anaesthetized rats of partially purified (Sephadex G 50 chromatography) fractions of normal rat ventrolateral hypothalamic (VLH) extracts. Absorbance $(\mathrm{O}-\mathrm{O}$ ) of the column at $280 \mathrm{~nm}$. The elution positions of labelled insulin, labelled glucagon and labelled somatostatin (SRIF) used as molecular weight marker are indicated. Note that analogous data are obtained with ventromedial hypothalamic extract [68]

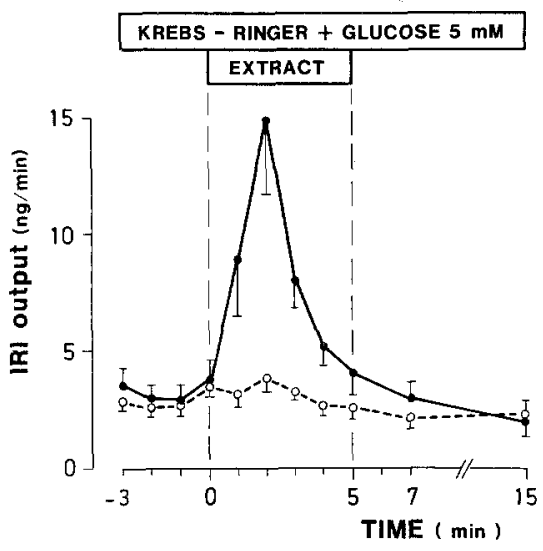

Fig. 22. Effects of infusions of cortical extract (controls, $O----O)$ or ventrolateral hypothalamic (VLH, - - ) extracts on insulin secretion by isolated perfused pancreases of normal rats. The VLH extract refers to the active ones on insulin output in vivo, i.e. those corresponding to the second peak of Figure 21. Means of 3-5 experiments \pm SEM [69]

since it is, most of the time, symptomatic in its nature. As long as CNS disorders (with their metabolic consequences) are not therapeutically altered, body weight is bound to return to a "higher set point" $[59,60]$.

As can be seen from Figure 20, there are many neural afferences originating from the periphery to reach the brain, CNS integration of these afferent informations with resulting neural efferences that influence peripheral organs [44, 61-64]. Several of these processes could be altered in obesity syndromes and we attempt studying them at the moment. We have shown for example that, when an oral glucose tolerance test is performed in conscious, freely moving genetically obese $(f a / f a)$ rats, such tolerance is abnormal while it is not when the same glucose load is given intravenously [65]. This could be due in part to abnormal neural afferent input (from the oropharynx or the gut) with defective or non-operative cephalic phase insulin output or other defective reflex mechanisms [66]. These defects could result in inappropriate timing and/or dynamics of meal-induced insulin output that, from the data of others [67], appears to have a strong influence on normal disposal of glucose. This or other defects in the integration of afferent information within the CNS would also result in the inability of ingested glucose and released insulin to shut off hepatic glucose production and/or to clear ingested glucose adequately, as has been recently suggested by this laboratory (J.Proietto, E. Ionescu and F. Rohner-Jeanrenaud, unpublished data).

Figure 20 also mentions the presence of several peptides. Some of them increase plasma glucose levels; others stimulate insulin secretion [22]. The physio- and pathological roles of these peptides are as yet unknown. We have made great efforts to study a hypothalamic peptide that possesses in vivo and in vitro insulin secretion promoting activity, as illustrated by Figure 21 and $22[68,69]$. Thus (Fig. 21) partially purified hypothalamic extracts (G-50 Sephadex chromatography) from normal rats produce, when injected in vivo to normal anaesthetized recipient rats, rapid and transient rises in plasma insulin levels. The factor(s) responsible for this effect is of small molecular weight. Catecholamines, acetylcholine and enkephalins can be excluded as causes of the effect observed. The finding that exposure of those partially purified extracts from ventrolateral hypothalamus (VLH) to trypsin or collagenase markedly decrease their in vivo insulin secretion promoting activity suggest that this active component(s) is of polypeptidic nature and is also thermostable [68]. Furthermore, as can be seen in Figure 22, when the active fractions of the partially purified hypothalamic extract (cf. Fig.21) are pooled and infused into normal perfused pancreases, a pronounced stimulatory effect on insulin secretion is observed at a low glucose concentration in the medium, indicating that the peptidic factor(s) is not an incretin [69]. This small peptide (about 1000 Daltons) appears to be present both in the hypothalamus and the plasma of normal rats and is currently being purified by HPLC; its amino-acid analysis is close to completion (E. Bobbioni, W.Schlegel and D. Ashley, unpublished data). It is hoped that we shall soon be able to deter- 
mine its amino acid sequence. Once the peptide is fully characterized, we shall raise an antibody against to set up a radio-immunoassay. This will allow us to determine its physiology and pathology: it is conceivable that such a study may re-inforce our overall concept (shown by Fig. 20) that obesity, possibly insulin resistance and the evolution toward Type 2 diabetes may both have a neurological basis.

Acknowledgements. Research has been supported by grants from the Swiss National Science Foundation, Berne; by grants-in-aid from Nestlé-Alimentana, Vevey; Zyma, Nyon; from the National Institutes of Health, Bethesda, MD; Fondation Emil Barell, Basel; Roche Research Foundation, Basel; Sandoz-Stiftung zur Förderung der Medizinischen-Biologischen Wissenschaften, Basel; Stiftung zur Förderung der Ernährungsforschung in der Schweiz, Berne; Fondation E. et L.Schmidheiny, Céligny; Société Académique de Genève, Geneva; Hoechst, Frankfurt/Main. We are grateful to the Swiss National Science Foundation, Berne and to Nestlé, Vevey for their continuous support over the years.

\section{References}

1. Jeanrenaud B (1971) Adipocytes, available energy and the endocrine pancreas. Diabetologia 7: 209-222

2. Assimacopoulos-Jeannet F, Exton JH, Jeanrenaud B (1973) Control of gluconeogenesis and glycogenolysis in perfused livers of normal mice. Am J Physiol 225: 25-32

3. Le Marchand Y, Singh A, Assimacopoulos-Jeannet F, Loten EG, Orci L, Rouiller Ch, Jeanrenaud B (1973) A role for the microtubular system in the release of very low density lipoproteins by perfused mouse livers. J Biol Chem 248: 6862-6870

4. Le Marchand Y, Patzelt Ch, Assimacopoulos-Jeannet F, Loten EG, Jeanrenaud B (1974) Evidence for a role of the microtubular system in the secretion of newly synthesized albumin and other proteins by the liver. J Clin Invest 53:1512-1517

5. Singh A, Le Marchand Y, Orci L, Jeanrenaud B (1975) Colchicine administration to mice: A metabolic and ultrastructural study. Eur J Clin Invest 5: 495-505

6. Patzelt Ch, Singh A, Le Marchand Y, Orci L, Jeanrenaud B (1975) Colchicine-binding protein of the liver: its characterization and relation to microtubules. J Cell Biol 66: 609-620

7. Prentki M, Chaponnier Ch, Jeanrenaud B, Gabbiani G (1979) Actin microfilaments, cell shape and secretory processes in isolated rat hepatocytes: effect of phalloidin and cytochalasin D. J Cell Biol 81: 592-607

8. Prentki M, Crettaz M, Jeanrenaud B (1981) Role of microtubules in insulin and glucagon stimulation of amino acid transport in isolated rat hepatocytes. J Biol Chem 256: 4336-4340

9. Assimacopoulos-Jeannet F, Singh A, Le Marchand Y, Loten EG, Jeanrenaud B (1974) Abnormalities in lipogenesis and triglyceride secretion by perfused livers of obese-hyperglycaemic (ob/ob) mice: relationship with hyperinsulinaemia. Diabetologia 10: 155-162

10. Karakash C, Hustvedt BE, Løvø A, Le Marchand Y, Jeanrenaud B (1977) Consequences of ventromedial hypothalamus lesions upon metabolism of perfues rat liver. Am J Physiol 232: E286-E293

11. Karakash C, Rohner-Jeanrenaud F, Hustvedt BE, Jeanrenaud B (1980) Nitrogen handling in adult hypothalamic obese rats. Am J Physiol 238: E32-E37

12. Loten EG, Rabinovitch A, Jeanrenaud B (1974) In vivo studies on lipogenesis in obese-hyperglycaemic (ob/ob) mice: Possible role of hyperinsulinaemia. Diabetologia 10: 45-52

13. Le Marchand $Y$, Freychet $P$, Jeanrenaud B (1978) Longitudinal study on the establishment of insulin resistance in hypothalamic obese mice. Endocrinology 102: 74-85

14. Le Marchand Y, Loten EG, Assimacopoulos-Jeannet F, For- gue ME, Freychet $P$, Jeanrenaud B (1977) Effect of fasting and streptozotocin in the obese-hyperglycemic $(o b / o b)$ mouse: Apparent lack of a direct relationship between insulin binding and insulin effects. Diabetes 26: 582-590

15. Bereiter DA, Jeanrenaud B (1979) Altered neuroanatomical organization in the central nervous system of the genetically obese ( $a b /$ ob) mouse. Brain Res 165: 249-260

16. Bereiter DA, Jeanrenaud B (1980) Altered dendritic orientation of hypothalamic neurons from genetically obese $(a b / a b)$ mice. Brain Res 202: 201-206

17. Karakash C, Assimacopoulos-Jeannet F, Jeanrenaud B (1976) An anomaly of insulin removal in perfused livers of obesehyperglycemic $(o b / o b)$ mice. J Clin Invest 57:1117-1124

18. Karakash C, Jeanrenaud B (1983) Insulin binding an removal by livers of genetically obese rats. Diabetes 32: 605-609

19. Assimacopoulos-Jeannet F, Jeanrenaud B (1976) The hormonal and metabolic basis of experimental obesity. In: Albrink MJA (ed) Clinics in endocrinology and metabolism, Vol 5. Saunders WB, pp 337-365

20. Le Marchand-Brustel Y, Jeanrenaud B (1978) Pre- and postweaning studies on the development of obesity in the $m \mathrm{db} / \mathrm{mdb}$ mice. Am J Physiol 234: E568-E574

21. Pénicaud L, Rohner-Jeanrenaud F, Jeanrenaud B. In vivo metabolic changes as studied longitudinally after ventromedial hypothalamic lesions. Submitted for publication

22. Jeanrenaud B, Halimi S, van de Werve G (1985) Neuroendocrine disorders seen as triggers of the triad: obesity - insulin resistance abnormal glucose tolerance. In: De Fronzo RA (ed) Diabetes/metabolism reviews, vol 1. John Wiley, New York (in press)

23. van de Werve G, Jeanrenaud B (1983) Impaired liver carbohydrate metabolism in obese rodents. Diabetes 32 (Suppl): 72A (Abstract)

24. Hue L, van de Werve G, Jeanrenaud B (1983) Fructose 2,6-bisphosphate in livers of genetically obese rats. Biochem J 214: 1019-1022

25. Terrettaz J, Assimacopoulos-Jeannet F, Jeanrenaud B Inhibition of hepatic glucose production by insulin in vivo in the rat: contribution of glycolysis. Submitted for publication

26. Cuendet GS, Loten EG, Jeanrenaud B, Renold AE (1976) Decreased basal, non-insulin stimulated glucose uptake and metabolism by skeletal, soleus muscle isolated from obese-hyperglycemic (ob/ob) mice. J Clin Invest 58: 1078-1088

27. Le Marchand-Brustel Y, Jeanrenaud B, Freychet $P$ (1978) Insulin binding and effects in the isolated soleus muscle of lean and obese mice. Am J Physiol 234: E348-E358

28. Crettaz M, Jeanrenaud B (1980) Postreceptor alterations in the states of insulin resistance. Metabolism 29:467-473

29. Zaninetti D, Crettaz M, Jeanrenaud B (1983) Dysregulation of glucose transport in hearts of genetically obese $(f a / f a)$ rats. Diabetologia 25: 525-529

30. Crettaz M, Prentki M, Zaninetti D, Jeanrenaud B (1980) Insulin resistance in soleus muscle from obese Zucker rats. Involvement of several defective sites. Ciochem J 186: 525-534

31. Loten EG, Jeanrenaud B (1974) Effects of cytochalasin B, colchicine and vincristine on the metabolism of isolated fat cells. Biochem J 140: 185-192

32. Karnieli E, Zarnowski MJ, Hissin PJ, Simpson IA, Salans LB, Cushman SW (1981) Insulin-stimulated translocation of glucose transport systems in the isolated rat adipose cell. Time course, reversal, insulin concentration dependence, and relationship to glucose transport activity. J Biol Chem 256: 4772-4777

33. Suzuki K, Kono T (1980) Evidence that insulin causes translocation of glucose transport activity to the plasma membrane from an intracellular storage site. Proc Natl Acad Sci (USA) 77: 2542-2545

34. Wardzala LJ, Jeanrenaud B (1981) Potential mechanism of insulin action on glucose transport in the isolated rat diaphragm: Apparent translocation of intracellular transport units to the plasma membrane. J Biol Chem 256: 7090-7093

35. Wardzala LJ, Jeanrenaud B (1983) Identification of the D-glucoseinhibitable cytochalasin B binding site as the glucose transporter in rat diaphragm plasma and microsomal membranes. Biochimica et Biophysica Acta $730: 49-56$ 
36. Jeanrenaud B (1979) Insulin and obesity. Diabetologia 17: $133-138$

37. Terrettaz J, Jeanrenaud B (1983) In vivo hepatic and peripheral insulin resistance in genetically obese $(f a / f a)$ rats. Endocrinology 112: 1346-1351

38. Proietto J. Rohner-Jeanrenaud F, Terrettaz J, Sauter JF, Ionescu E, Jeanrenaud $B$ Validation of the non steady state measurement of glucose turnover in the rat. Submitted for publication

39. Terrettaz J. Jeanrenaud B Severe hepatic and peripheral insulin resistance as evidenced by euglycemic clamps in genetically obese $f a / f a$ rats. Submitted for publication

40. van de Werve G, Assimacopoulos-Jeannet F, Jeanrenaud B (1983) Altered liver glycogen metabolism in fed genetically obese mice. Biochem J 216: 273-280

41. van de Werve G, Jeanrenaud B (1984) Liver glycogen metabolism in starved-refed lean and genetically obese $(f a / f a)$ rats. Diabetologia 27:341A

42. Rohner F, Dufour AC, Karakash C, Le Marchand Y, Ruf KB, Jeanrenaud B (1977) Immediate effect of lesion of the ventromedial hypothalamus area upon glucose-induced insulin secretion in anesthetized rats. Diabetologia 13: 239-242

43. Berthoud HR, Jeanrenaud B (1979) Acute hyperinsulinemia and its reversal by vagotomy after lesions of the ventromedial hypothalamus in anesthetized rats. Endocrinology 105: 146-151

44. Rohner-Jeanrenaud F, Bobbioni E, Ionescu E, Sauter JF, Jeanrenaud B (1983) Central nervous system regulation of insulin secretion. In: Szabo AJ (ed) Advances in metabolic disorders, Vol 10. Academic Press, New York, pp 193-220

45. Bereiter DA, Bethoud HR, Brunsmann MJA, Jeanrenaud B (1981) Nucleus ambiguus stimulation increases plasma insulin levels in the rat. Am J Physiol 241: E22-E28

46. Ionescu E, Rohner-Jeanrenaud F, Berthoud HR, Jeanrenaud B (1983) Increases in plasma insulin levels in response to electrical stimulation of the dorsal motor nucleus of the vagus nerve. Endocrinology 112: 904-910

47. Sauter JF, Niijima A, Berthoud HR, Jeanrenaud B (1983) Vagal neurons and pathways to the rat's lower viscera: an electrophysiological study. Brain Res Bull 11: 487-491

48. Bereiter DA, Berthoud HR, Becker MJA, Jeanrenaud B (1982) Brain stem infusion of the $\gamma$-aminobutyric acid antagonist bicuculline increases plasma insulin levels in the rat. Endocrinology 111: $324-328$

49. Rohner-Jeanrenaud F, Jeanrenaud B (1980) Consequences of ventromedial hypothalamic lesions upon insulin and glucagon secretion by subsequently isolated perfused pancreases in the rat. J Clin Invest 65:902-910

50. Rohner-Jeanrenaud F, Jeanrenaud B (1981) Possible involvement of the cholinergic system in hormonal secretion by the perfused pancreas from ventromedial-hypothalamic lesioned rats. Diabetologia 20: 217-222

51. Rohner-Jeanrenaud F, Jeanrenaud B (1984) Oversecretion of glucagon by pancreases of ventromedial hypothalamic-lesioned rats: a re-evaluation of controversial topic. Diabetologia 27:529-534

52. Niijima A, Rohner-Jeanrenaud B, Jeanrenaud B (1984) Role of ventromedial hypothalamus on sympathetic efferents of brown adipose tissue. Am J Physiol 247: R650-R654

53. Seydoux J, Rohner-Jeanrenaud F, Assimacopoulos-Jeannet F, Jeanrenaud B, Girardier L (1981) Functional disconnection of brown adipose tissue in hypothalamic obesity in rats. Pflügers Arch 390: 1-4

54. Rohner-Jeanrenaud F, Seydoux J, Chinet A, Bas S, Giacobino JP,
Assimacopoulos-Jeannet F, Jeanrenaud B, Girardier L (19821983) Defective diet-induced but normal cold-induces brown adipose tissue adaptation in hypothalamic obesity in rats. J Physiol (Paris) 78: 833-837

55. Seydoux J, Assimacopoulos-Jeannet F, Jeanrenaud B, Girardier L (1982) Alterations of brown adipose tissue in genetically obese (ob/ob) mice. I. Demonstration of loss of metabolic response to nerve stimulation and catecholamines and its partial recovery after fasting or cold adaptation. Endocrinology 110: 432-438

56. Assimacopoulos-Jeannet F, Giacobino JP, Seydoux J, Girardier L, Jeanrenaud B (1982) Alterations of brown adipose tissue in genetically obese $(o b / o b)$ mice. II. Studies of $\beta$-adrenergic receptors and fatty acid degradation Endocrinology 110: 439-443

57. Rohner-Jeanrenaud F, Hochstrasser AC, Jeanrenaud B (1983) Hyperinsulinemia of preobese and obese $f a / f a$ rats is partly vagus nerve mediated. Am J Physiol 244: E317-E322

58. Rohner-Jeanrenaud F, Jeanrenaud B (1985) Involvement of the cholinergic system in insulin and glucagon oversecretion of genetic pre-obesity. Endocrinology 116: 830-834

59. Wardzala LJ, Crettaz M, Horton ED, Jeanrenaud B, Horton ES (1982) Physical training of lean and genetically obese Zucker rats: effect on fat cell metabolism. Am J Physiol 243: E418-E426

60. Crettaz M, Horton ES, Wardzala LJ, Horton ED, Jeanrenaud B (1983) Physical training of Zucker rats: lack of alleviation of muscle insulin resistance. Am J Physiol 244: E414-E420

61. Bereiter D, Berthoud HR, Jeanrenaud B (1980) Hypothalamic input to brain stem neurons responsive to oropharyngeal stimulation. Exp Brain Res 39: 33-39

62. Bereiter DA, Berthoud HR, Jeanrenaud B (1981) Chorda tympani and vagus nerve convergence onto caudal brainstem neurons in the rat. Brain Res Bull 7:261-266

63. Berthoud HR, Jeanrenaud B (1982) Sham feeding-induced cephalic phase insulin release in the rat. Am J Physiol 242: E280-E285

64. Szabo J, Szabo O (1982) Insulin-sensitive glucoregulator chemoreceptors in the central nervous system: their putative role in glucose homeostasis. In: Litwack G (ed) Biochemical action of hormones, vol 9, Academic Press, New York, pp 93-113

65. Ionescu E, Sauter JF, Jeanrenaud B (1985) Abnormal oral glucose tolerance in genetically obese $(f a / f a)$ rats. Am J Physiol (in press)

66. Ionescu E, Rohner-Jeanrenaud F, Rivest RW, Jeanrenaud B Cephalic phase insulin secretion in the genetically obese $(f a / f a)$ rats. Submitted for publication

67. Steffens $A B$ (1981) The regulatory role of the central nervous system on insulin and glucagon release during food intake in the rat. In: Dumont JE and Nunez J (eds) Hormones and cell regulation, vol 5. Inserm European Symposium, Elsevier North Holland Biomed Press, Amsterdam, pp 185-196

68. Bobbioni E, Jeanrenaud B (1982) Effect of rat hypothalamic extract administration on insulin secretion in vivo. Endocrinology 110: $631-636$

69. Bobbioni E, Jeanrenaud B (1983) A rat hypothalamic extract enhances insulin secretion in vitro. Endocrinology 113: 1958-1962

Professor Bernard Jeanrenaud

Laboratoires de Recherches Métaboliques

University of Geneva Medical School

64 avenue de la Roseraie

CH-1211 Geneva 4

Switzerland 